\title{
Film-Forming Polymers and Surfactants Reduce Infection and Sporulation of Phytophthora ramorum on Rhododendron
}

\author{
Ebba K. Peterson, ${ }^{1, \dagger}$ Eric R. Larson, ${ }^{2}$ and Jennifer L. Parke ${ }^{1,2}$ \\ ${ }^{1}$ Department of Botany and Plant Pathology, Oregon State University, Corvallis, OR 97331; and ${ }^{2}$ Department of Crop and Soil \\ Science, Oregon State University, Corvallis, OR 97331
}

\begin{abstract}
Phytophthora ramorum, cause of sudden oak death and ramorum leaf blight, can persist undetected in infested nurseries. Many conventional fungicides are effective in reducing or delaying symptom expression but some may confound visual detection of infected plants. We tested film-forming polymers (FFPs) and surfactants for their ability to reduce infection and sporulation of $P$. ramorum on rhododendron. FFPs (Anti-Stress, Moisturin, Nature Shield, Nu-Film, and Vapor Gard) and surfactants (Tergitol, Zonix, and an unregistered AGAE product) were screened in detachedleaf assays. Anti-Stress, Nu-Film, Zonix, and a Nu-Film-Zonix mixture were additionally tested for durability, protection against exposure to infested

water, and a reduction in sporulation. FFP effectiveness was retained for at least 3 weeks of exposure to overhead irrigation and rain. Relative to controls, foliar treatments protected rhododendron branches exposed to infested water. No treatments prevented symptom development when applied postinfection but leaves treated with Anti-Stress, Zonix, and the Nu-FilmZonix mixture produced significantly fewer sporangia relative to controls. Application of FFPs and surfactants to quarantined, potentially infected plants offers a management tool for reducing infection and sporulation but not symptom expression, thereby limiting disease spread without interfering with disease detection.
\end{abstract}

Phytophthora ramorum (Werres, DeCock \& Man in't Veld) has been implicated in the rapid death of certain species of the Fagaceae family native to California and Oregon, particularly tanoak (Notholithocarpus densiflorus, syn. Lithocarpus densiflorus) and some red oak species (Quercus section Lobatae) (Ellison et al. 2005; McPherson et al. 2010; Rizzo et al. 2002). This disease, termed sudden oak death, was first detected in coastal Californian forests in 1995 (Rizzo et al. 2002). Since that time, P. ramorum has been found in nurseries and gardens within North America and Europe, and has more recently been reported causing Japanese larch mortality in the United Kingdom (Brasier and Webber 2010; Grünwald et al. 2012).

$P$. ramorum also causes a nonlethal leaf blight on over 100 different plant species in over 35 genera, including a number of ornamentals commonly grown in commercial nurseries (USDA-APHIS 2013). The inadvertent shipment of infested $P$. ramorum plants is the most likely introduction pathway of this pathogen to and within the western United States (Goss et al. 2009; Grünwald et al. 2012), sometimes resulting in new forest introductions (Kamvar et al. 2015). To prevent pathogen spread, quarantine and eradication measures such as plant destruction, treatment of irrigation water, soil steaming, and soil solarization are implemented in regulated nurseries when this pathogen is detected. These measures are costly to commercial producers, and repeat detections in subsequent surveys

${ }^{\dagger}$ Corresponding author: E. K. Peterson;

E-mail: peterebb@science.oregonstate.edu

Funding: Funds for this work were provided by a grant from the Oregon Department of Agriculture Nursery Research Program.

Disclaimer: Inclusion of commercial products in the research reported here implies no endorsement by the authors or Oregon State University. Criticism of products listed is not implied or intended. Due to continually changing laws and regulations, the authors and Oregon State University assume no liability for the suggested use of chemicals contained herein. All pesticides should be applied according to the label directions on the pesticide container.

The author(s) declare no conflict of interest.

Accepted for publication 10 January 2019.

C 2019 The American Phytopathological Society remain a problem despite eradication and sanitation efforts (Chastagner et al. 2013; COMTF 2016). Unfortunately, limited chemical treatment options are available once $P$. ramorum has established within a nursery.

Many classes of systemic and contact fungicides have been screened for effectiveness in treating and preventing infection by $P$. ramorum. None have been shown to eliminate $P$. ramorum from infected plants (Elliott et al. 2015; Linderman and Davis 2008; Tjosvold et al. 2008). Fosetyl-Al and mefanoxam are the most commonly used protectants, though these materials are fungistatic rather than fungicidal and their use, in the case of mefanoxam, increases the risk of resistance development (Chastagner et al. 2010; Elliott et al. 2015; Linderman and Davis 2008; Pérez-Sierra et al. 2011; Silva et al. 2016; Tjosvold et al. 2008; Vercauteren et al. 2010). Plants that are subjected to postshipping quarantines or are held while infestations are delimited should not be treated with fungicides which interfere with the visual detection of infection (Tjosvold et al. 2008; USDA-APHIS 2011). Thus, $P$. ramorum can persist and potentially spread while being quarantined. Treatments that would limit disease spread from infected plants without affecting symptom development would be a helpful management tool in these certain circumstances.

Film-forming polymers (FFPs) and surfactants are widely used in the production of nursery stock. They are predominantly applied as stickers or spreaders to improve the adherence and distribution of pesticides or to reduce water vapor loss, ameliorating water stress and improving water use efficiency and yield under drought (Gale and Hagan 1966). These compounds may additionally be used as a means of disease management.

Disease protection by FFPs has been reported for a variety of crops, against a correspondingly diverse group of pathogens. Efficacy has been reported for leaf rust of wheat (causal agent: Puccinia recondita f. sp. tritici) (Zekaria-Oren et al. 1991), leaf blight of lily (Botrytis elliptica) (Hsieh and Huang 1999), apple scab (Venturia inequalis) (Percival and Boyle 2009), and powdery mildew of oak (Microphaera alphitoides) (Percival et al. 2006]), among others. Depending upon their formulation, films either create a physical barrier that prevents adhesion of spores and leaf penetration, alter leaf topography and host recognition, or chemically inhibit spore germination (Elad et al. 1990; Gale and Hagan 1966; Haggag 2002; Hsieh and Huang 1999; Percival and Boyle 2009; Walters 2006; ZekariaOren et al. 1991; Ziv and Frederiksen 1987). To our knowledge, only one study thus far has demonstrated the efficacy of FFPs in 
the reduction in disease by an oomycete (Phytophthora infestans) (Haggag and El-Khair 2007).

Disease reduction properties of surfactants are also diverse. Of particular utility are rhamnolipids, a group of glycolipid biosurfactants produced by Pseudomonas spp. and other microorganisms (de Souza et al. 2003; Nielsen et al. 2002; Vatsa et al. 2010). Applied to soil or recirculating water systems, surfactants affect membrane and cell wall integrity of organisms in numerous taxonomic groups, including bacteria, fungi, and zoosporic plant pathogens (Ron and Rosenberg 2001; Stanghellini and Miller 1997; Stanghellini and Tomlinson 1987; Vatsa et al. 2010). Others may also reduce mycelial growth or induce plant immune responses (D'aes et al. 2010; Perneel et al. 2008; Varnier et al. 2009; Vatsa et al. 2010). Within the phylum Oomycota, evidence suggests that surfactants are protective against several root-infecting pathogens, including that of pepper by Phytophthora capsici (Nielsen et al. 2006; Stanghellini et al. 1996a), brown root rot of witloof chicory (P. cryptogea) (De Jonghe et al. 2005), and root rot of cucumber (Pythium aphanidermatum) (Stanghellini et al. 1996b). The only reports of protection against a foliar-infecting oomycete include white rust of spinach (Albugo occidentalis) (Irish et al. 2002), and foliar infection of pepper by Phytophthora capsici (Kim et al. 2000).

Despite their efficacy in hydroponic systems, the addition of surfactants to large volumes of irrigation water is impractical, limiting their use in other horticultural production systems. Effectiveness of surfactants as a foliar spray is likely to be enhanced by compounds containing some adherence properties. In this regard, FFPs may be a viable treatment option. Given their efficacy against other pathogens, FFPs and surfactants (or a combination of the two) may provide protection against foliar Phytophthora spp., including P. ramorum.

Our objective was to evaluate the potential for FFPs and surfactants, alone or in combination, to reduce the spread of $P$. ramorum from rhododendron without interfering with disease detection. Rhododendron is one of the two most commonly infected nursery hosts in the United States and Europe, is often associated with inadvertent interstate shipping of Phytophthora-infested nursery stock, and is responsible for epidemic development in the United Kingdom (Brasier et al. 2004; Cave et al. 2008; COMTF 2016; Grünwald et al. 2008; Haun and Hebbar 2011; Tjosvold et al. 2005, Tubajika et al. 2006).

After screening an initial set of compounds with a detached-leaf assay, the most effective FFPs and surfactants were further tested in three experiments: to test the durability of treatments over time when applied to plants in an experimental container yard; to test for protection against exposure to infested surface water; and, finally, to determine whether these compounds can reduce sporulation of $P$. ramorum when applied to infected leaves.

\section{Materials and Methods}

Inoculum production. $P$. ramorum isolate Pr-05-002 (NA2 lineage), shown to be aggressive on rhododendron (Manter et al. 2010), was used in all laboratory experiments. For those experiments utilizing zoospores as inoculum, zoospores were prepared using 3-weekold cultures of $P$. ramorum grown on $1 / 3$ V8 juice agar. Cultures were flooded with deionized (DI) water and scraped with a rubber spatula. The sporangial suspension was placed at $4{ }^{\circ} \mathrm{C}$ for $1 \mathrm{~h}$ followed by 30 to $60 \mathrm{~min}$ at $20^{\circ} \mathrm{C}$. Once zoospores were released, the suspension was filtered through a $20-\mu \mathrm{m}$ nylon mesh before dilution with DI water to the desired concentration.

Screening of selected FFPs and surfactants with the detachedleaf assay. For the initial screening to determine which compounds to include in additional trials, FFPs (Anti-Stress 2000, Moisturin, Nature Shield, Nu-Film P, and Vapor Gard) and surfactants (Zonix, Tergitol NP7, and an unregistered biosurfactant from AGAE Technologies LLC) (Table 1) were tested in detached-leaf assays. FFPs were diluted with DI water to achieve a 0.5 or $10 \%$ concentration (vol/vol); surfactants were tested at 100, 400, and 1,000 ppm active ingredient. DI water was used as a control for all experiments. The abaxial sides of harvested, nonwounded Rhododendron 'Roseum Elegans' leaves were evenly coated using an air brush sprayer (Model 250.4; Badger Air-Brush Co., Franklin Park, IL, U.S.A.) and excess compound was drained off. Leaves (10 per treatment) were allowed to dry overnight prior to inoculation.

Leaves were inoculated on their abaxial side by dispensing three $100-\mu l$ aliquots of zoospore suspension $\left(2 \times 10^{4}\right.$ zoospores $\left./ \mathrm{ml}\right)$ on each side of the midrib (600 $\mu$ l per leaf). Once applied, the drops were spread using a rubber policeman and left for $2 \mathrm{~min}$ before excess zoospore suspension was drained off. Inoculated leaves were placed adaxial side up upon moist paper towels laid on screens suspended over a pool of water within lidded plastic tubs. Leaves were then covered with a second moist paper towel, and were periodically misted with DI water to prevent drying during incubation. The tubs were left at $20^{\circ} \mathrm{C}$ for 10 days before scanning on a flatbed scanner and measuring percent lesion area (Assess v. 1.0; American Phytopathological Society, St. Paul, MN, U.S.A.). Lesion area was assessed rather than lesion count as in preliminary trials; the two measures were strongly correlated (data not shown). Furthermore, rapid lesion expansion made lesion number counts unreliable at higher levels of infection. A subset of lesions from each treatment was plated in Phytophthoraselective media (ampicillin at $200 \mathrm{ml} / \mathrm{liter}$, rifamycin at $10 \mathrm{mg}$ / liter, and pentachloronitrobenzene at $66.7 \mathrm{mg} / \mathrm{liter}$ ) to verify infection by $P$. ramorum, as confirmed by characteristic spore and hyphal morphology (Werres et al. 2001). The surfactant and FFP trials were performed and analyzed separately, comparing average percent lesion area between treatments. Each experiment was performed twice.

Durability over time. This experiment was designed to test the durability of the applied materials when subjected to overhead irrigation. For each trial, number 1 pots containing Rhododendron 'Roseum Elegans' plants were moved to an experimental container yard located in Corvallis, OR for a minimum of 10 days to harden off prior to the application of experimental compounds.

For trial 1, started 19 September 2014, 10 plants/treatment were sprayed from the side, using an air brush sprayer with one of the following treatments: Zonix (500 or 1,000 ppm), Anti-Stress (5\%), $\mathrm{Nu}$-Film (5\%), or DI water (untreated controls). For trial 2, started 10 October 2014, eight plants per treatment were sprayed with the same compounds and an additional treatment of $500 \mathrm{ppm}$ Zonix combined with $2.5 \% \mathrm{Nu}$-Film. The compounds were applied to runoff, and excess material was lightly shaken off. The sprays ensured the

Table 1. Film-forming polymers and surfactants evaluated for the control of ramorum leaf blight on Rhododendron 'Roseum Elegans'

\begin{tabular}{llll}
\hline Product & \multicolumn{1}{c}{ Components } & Marketed property & \multicolumn{1}{c}{ Manufacturer } \\
\hline Anti-Stress 2000 & Acrylic polymer & Antitranspirant & Polymer Ag LLC (Orange Grove, CA) \\
Moisturin & $\begin{array}{l}\text { 2,2,4-Trimethyl-1,3-pentanediol } \\
\text { monoisobutyrate }\end{array}$ & Antitranspirant & Horticultural (Bend, OR) \\
Nu-Film P & $\begin{array}{l}\text { Pinene (polyterpenes) polymers, petrolatum, } \\
\text { alkyl amine ethoxylate }\end{array}$ & Spreader/sticker & Miller Chemical and Fertilizer Co. (Hanover, PA) \\
& $\begin{array}{l}\text { Ethylene glycol monobutyl ether } \\
\text { Nature Shield }\end{array}$ & Antitranspirant & Nature Sciences LLC (La Center, WA) \\
Vapor Gard & Di-1-p-menthene & Antitranspirant & Miller Chemical and Fertilizer Co. (Hanover, PA) \\
AGAE & Rhamnolipid biosurfactant & Surfactant & AGAE Technologies LLC (Corvallis, OR) \\
Tergitol-NP7 & Nonylphenol ethoxylate & Surfactant & Dow Chemical Company (Midland, MI) \\
Zonix & Rhamnolipid biosurfactant & Surfactant/biofungicide & Jeneil Biosurfactant Company (Saukville, WI) \\
\hline
\end{tabular}


application of compounds to both leaf surfaces (abaxial and adaxial). Plants were then placed on wood pallets underneath a shade structure in a randomized block design utilizing four blocks to account for variations in exposure to sunlight and irrigation intensity.

Plants were automatically irrigated twice daily with $30 \mathrm{~min}$ of overhead irrigation (Rain Bird MPR-15Q nozzle). Because rainfall increased at the beginning of the second trial, the overhead watering was shut off. To quantify the amount of water applied from the sprinklers, 16 buckets (each 18.9 liters in volume and $30.48 \mathrm{~cm}$ in diameter) were evenly placed throughout the container yard prior to setting out the plants. The volume of water captured during a 30min irrigation cycle was measured for each bucket, which was used to calculate the daily average amount of irrigated water throughout the plot. Additional daily weather data (precipitation and temperature) were obtained from the Corvallis, OR Agrimet weather station (https://www.usbr.gov/pn/agrimet/). For days in which minor precipitation was measured and the sprinklers were on, we combined the two to calculate the total daily precipitation.

Two hours after plants were treated but prior to watering, three leaves from each plant were removed (time 0 ) and moved into the lab; additional sets of leaves were removed at weekly intervals for 4 weeks (weeks 1 to 4 ). Leaves were challenged with $P$. ramorum zoospores $\left(2 \times 10^{4}\right.$ zoospores $/ \mathrm{ml}$ concentration $)$ utilizing a detached-leaf assay as described above. Average lesion area was compared between all treatments within a single time period and over time for each individual treatment.

Exposure to infested water. This experiment was designed to determine whether materials applied to plants would protect them from infection if they tipped over into nursery surface water infested with Phytophthora zoospores. Potted 7.5 liter Rhododendron 'Roseum Elegans' plants were sprayed with DI water, 5\% Anti-Stress, 5\% Nu-Film, a 2.5\% Nu-Film and 500 ppm Zonix mixture, and a 5\% $\mathrm{Nu}-$ Film and 1,000 ppm Zonix mixture (three plants per treatment) using a hand-pump backpack sprayer capable of obtaining pressures up to $413 \mathrm{kPa}$ and fitted with the standard adjustable nozzle (model 473-D; Solo, Newport News, VA, U.S.A.). Each plant was sprayed individually for $1 \mathrm{~min}$, which was sufficient for solutions to run off. Plants were then lightly shaken to remove excess compound. To simulate leaf exposure to infested puddle water during plant tip over, 14 branch tips per treatment were removed 1 day after being sprayed and dipped in $600 \mathrm{ml}$ of $P$. ramorum zoospore suspension $\left(4.7 \times 10^{4}\right.$ or $7.0 \times 10^{4}$ zoospores $/ \mathrm{ml}$ for trials 1 and 2 , respectively) for $4 \mathrm{~min}$. Each treatment was dipped in its own individual zoospore suspension; the depth was sufficient to expose all leaves on each branch. Branches were then placed between moist paper towels within plastic tubs and incubated for 7 days at $20^{\circ} \mathrm{C}$ before scanning leaves and measuring percent lesion area for all leaves on each branch. Analysis was conducted on the average lesion area per branch. This experiment was performed twice.

Prevention of sporulation. Finally, we sought to determine whether FFPs and surfactants would prevent sporulation when applied after infection has occurred. Detached Rhododendron 'Roseum Elegans' leaves were first inoculated with $P$. ramorum by wounding each leaf three times on each side of the midvein. A zoospore suspension $\left(100 \mu \mathrm{l}\right.$ at $2 \times 10^{4}$ zoospores $\left./ \mathrm{ml}\right)$ was applied to each wound on the abaxial side. The leaves were incubated for 4 days on moist paper towels in crisper boxes to allow infection to establish. After this time, but before the development of symptoms, treatments (5\% AntiStress, 5\% Nu-Film, 500 ppm Zonix, 1,000 ppm Zonix, and a mixed solution with a final concentration of $1,000 \mathrm{ppm}$ Zonix and $5 \% \mathrm{Nu}-$ Film; 10 leaves per treatment) were applied to both sides of the leaf using the air brush sprayer. Leaves were then placed abaxial side up on screens within incubation tubs, left uncovered, and incubated an additional 4 days with daily mistings of DI water to stimulate the production of sporangia.

After incubation, each leaf was placed in a 50-ml tube (Falcon brand; Corning, Inc., Corning, NY, U.S.A.), abaxial side facing in toward the center, with approximately $30 \mathrm{ml}$ of DI water. Tubes were vortexed, leaves were removed, and the water was filtered through a 5 - $\mu \mathrm{m}$ filter. The tube was rinsed twice with DI water to remove residual sporangia. Filters were then stained with a $1 \%(\mathrm{~g} / \mathrm{vol})$ solution of Calcofluor White (Millipore-Sigma, St. Louis, MO, U.S.A.) and sporangia were counted along two perpendicular transects of each filter at $\times 100$ magnification using a Zeiss Axiostar epifluorescence microscope (Carl Zeiss MicroImaging, Inc., Thornwood, NY, U.S.A.) fitted with a 425-nm emission filter. Leaves were then scanned to measure percent lesion area. This experiment was performed twice.

Statistical analysis. All analyses were performed in R (ver. 2.13) (R Core Team 2015). A generalized least-squares model (via the gls function in the nlme package) accounting for heteroscedasticity between treatments was used to model treatment affect upon percent lesioned area. This was applicable to the following experiments: initial detached-leaf screenings, durability over time, exposure to infested water, and lesion development in the prevention of sporulation trial. We excluded any treatments from analysis if no leaves were infected by $P$. ramorum in both trials. To test for efficacy at a given time period in the container yard durability trial, we modeled percent lesioned area for all treatments and controls within a single time period. To test for a decline in efficacy over time, we normalized percent lesioned area as a percentage of the control for each time period, then analyzed each treatment separately with time as a response variable. Changes in efficacy over time were determined significantly different at $\alpha=0.05$.

To compare the number of sporangia counted in the sporulation trial, we used a negative binomial model utilizing the glm.nb function in the MASS package. In this analysis, we used the offset function correcting for individual lesion size in the model.

Treatment and treatment-trial interaction effects were determined for each model by an analysis of variance. For experiments in which treatment-trial interactions were nonsignificant, all data were pooled. When treatment was significant, we performed posthoc analysis to determine differences between treatments with a Fischer's least significant difference test using the package predictmeans.

\section{Results}

Screening FFPs and surfactants. For the trials including the application of all five FFPs (Anti-Stress, Moisturin, Nu-film, Nature Shield, and Vapor Gard) at 0.5 and $10 \%$ concentration, marginal treatment differences were observed for all treatment which developed lesions $(P=0.0586)$. No lesions developed on leaves treated with $10 \%$ Anti-Stress or $10 \%$ Moisturin in either trial and these treatments were excluded from further statistical analyses. Among the remaining treatments, $10 \%$ Vapor Gard, $10 \% \mathrm{Nu}$-film, $10 \%$ Nature Shield, and $0.5 \%$ Anti-Stress had significantly lower percent lesioned area relative to controls in posthoc analysis (Fig. 1).

Significant differences were detected between one or more surfactant treatments $(P<0.001)$. Leaves treated with AGAE at 400 and $1,000 \mathrm{ppm}$, Tergitol at 400 and $1,000 \mathrm{ppm}$, or Zonix at 1,000 ppm concentration had significantly smaller percent lesioned area relative to the controls (Fig. 2). No treatments significantly reduced percent lesion area when applied at $100 \mathrm{ppm}$, the lowest concentration tested (Fig. 2).

Durability over time. Percent lesion area was greatest for the control group for most time periods and treatments in both trials (Table 2). The effect of time upon lesion size differed between the two trials for most treatments; therefore, each trial was analyzed separately. In trial 1 , there was no significant change in lesion size over 4 weeks for all treatments $(\alpha=0.05)$. In trial 2 , efficacy differed significantly over time for at least one time period for all treatments except for 1,000 ppm Zonix ( $\alpha=0.05)$. Overall, the Zonix treatments were the least effective over time; leaves treated with $\mathrm{Nu}$-Film or a $\mathrm{Nu}-$ Film and Zonix combination (trial 2 only) had the lowest percent lesioned area (Table 2).

Across the buckets assessing water distribution, an average of $0.7 \mathrm{~cm}$ of water was applied per day (range: 0.34 to $1.24 \mathrm{~cm}$ ) during days in which the plot was irrigated. During the first trial, there were three storm events during which plants were exposed to water via both irrigation and rain; storm frequency increased in the second trial (Fig. 3). 
Exposure to infested surface water. All treatments significantly reduced average lesion area relative to controls $(P<0.001)$. Plants treated with DI water (control) had the greatest average lesioned area per branch (Fig. 4).

Prevention of sporulation. We detected significant differences between sporangia production for some treatments $(P<0.001$; Fig. 5B) despite no significant difference in percent lesion area observed between the control and treatments $(P=0.7274$; Fig. 5A). Leaves treated with Anti-Stress, 500 and 1,000 ppm Zonix, and the Zonix-Nu-Film mixture produced significantly fewer sporangia relative to controls (Fig. 5B). Nu-Film did not significantly reduce the number of sporangia produced (Fig. 5B).

\section{Discussion}

In this study, we have identified compounds with potential to reduce infection and sporulation of $P$. ramorum from rhododendron, a host considered largely responsible for the movement of this invasive phytopathogen between nurseries. In contrast to much of the prior work on FFPs and surfactants, we considered multiple stages within the disease cycle in which these compounds might alter the disease trajectory (infection, lesion expansion, and sporulation), and demonstrated that a combination treatment had greater efficacy than each treatment alone.

Because no single surfactant or FFP performed remarkably better than the others in our first screening trials, the selection of compounds to pursue in subsequent trials took into consideration mode of action, feedback from industry growers, and current registration as a fungicide. In this manner, Anti-Stress 2000 and Nu-Film P were both selected as FFPs of interest, and Zonix was chosen as the surfactant. Because Nu-Film performed best in the first outdoor container trial, we chose to focus our continuing efforts on testing a combination treatment containing Nu-Film and Zonix.

Anti-Stress and Nu-Film were included to represent the two FFP classes and modes of action: latex-based polymers which provide a physical barrier against penetration (Anti-Stress), or terpene or other chemical-based products which may additionally prevent the successful germination or growth of pathogens (Nu-Film). Marketed as an antitranspirant, Anti-Stress has a labeled rate for ornamentals of $46 \mathrm{ml} /$ liter. Nu-Film is marketed as a sticker-spreader to aid the distribution and adhesion of pesticides, with a labeled rate for ornamentals of $280 \mathrm{ml}$ to 1.2 liter per hectare. Prior studies into FFPs indicate efficacy of both classes against fungal pathogens although, of

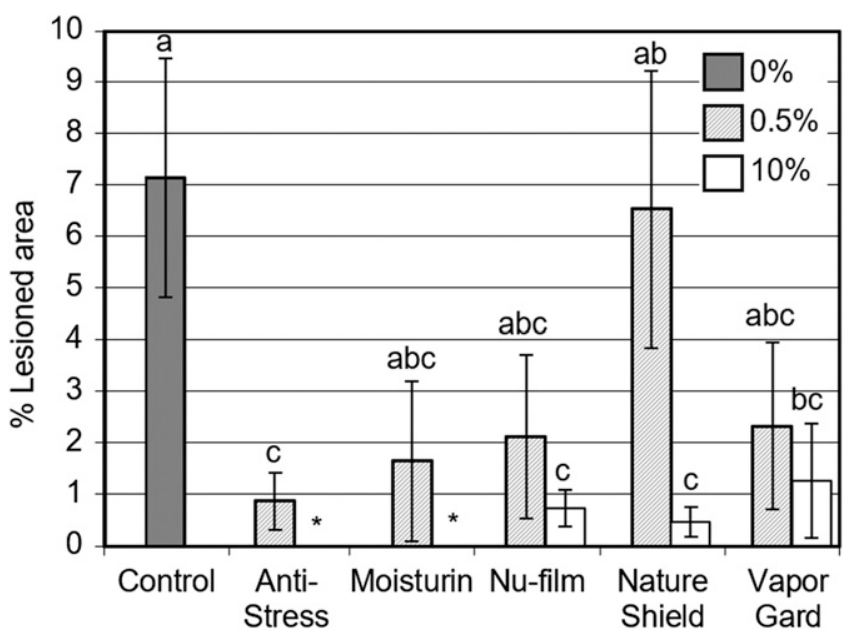

Fig. 1. Assay of all film-forming polymer (FFP) treatments used to determine which compounds to use for further testing. Percent lesioned area was measured 10 days after application of Phytophthora ramorum zoospores to nonwounded rhododendron leaves treated 1 day prior with FFP solutions diluted to 0.5 or $10 \%$ concentration with deionized (DI) water, or a DI water control $(n=20)$. Data for two trials are combined. No lesions developed for $10 \%$ Anti-Stress and $10 \%$ Moisturin treatments in either trial (indicated with asterisks). Bars represent standard error. Lowercase letters indicate significant differences between means as detected with a Fischer's least significant difference test $(P<0.05)$. the two, only Nu-Film has been evaluated in prior research (Haggag 2002; Haggag and El-Khair 2007; Percival and Boyle 2009; Walters 1992).

Zoospore lysis is the most likely mode of action of Zonix in our assays, given the application of zoospores for artificial inoculations. Zoospore lysis was confirmed through microscopic examination of $P$. ramorum zoospores postexposure to Zonix at $10,100,500$, or $1,000 \mathrm{ppm}$, concentrations which prevented the infection of rhododendron leaf disks in preliminary trials (data not shown). In addition to a 500-ppm concentration, the high end of labeled rates, we also tested Zonix at $1,000 \mathrm{ppm}$ in the container yard durability trial due to its greater efficacy in the screening trials and because of concerns about declining efficacy with exposure to overhead irrigation. Despite these concerns, a concentration of $500 \mathrm{ppm}$ is likely as effective as 1,000 ppm; whereas the 1,000-ppm treatment reduced lesion area relative to controls over most time periods in the first durability trial when the 500-ppm treatment did not, there was no significant difference in efficacy between the two rates at any time period (Table 2). Both also performed poorly relative to the FFPs, and failed to significantly reduce lesion area by the first week in the second trial (Table 2). A lower rate of $500 \mathrm{ppm}$ was also effective in combination with $\mathrm{Nu}-$ Film at preventing disease development in later experiments.

Throughout the trials treating whole plants, those treated with DI water had consistently greater disease as measured by percent lesion area in the detached-leaf assay (durability trial; Table 2) and detached-branch assay (infested surface water trial; Fig. 4). Although plant-to-plant spread is the dominant dispersal mechanism of $P$. ramorum in forests (Davidson et al. 2005; Eyre et al. 2013), exposure to infested surface water, such as when a plant tips into an infested puddle, may be equally or more important in initiating epidemics in nurseries (Heungens et al. 2010, 2013). All FFP and FFP + surfactant treatments were highly effective in protecting against exposure to a simulated puddle dip, including the lower-dosage Zonix and Nu-film combination (Fig. 4).

We additionally tested the capacity for these compounds to prevent sporulation. Being polycyclic, dispersal of inoculum from infected plants plays a significant role in the development of $P$. ramorum epidemics. Among FFPs, Nu-Film performed best in the outdoor durability trials but was the least effective treatment in preventing sporangia production. The combination of Nu-Film and

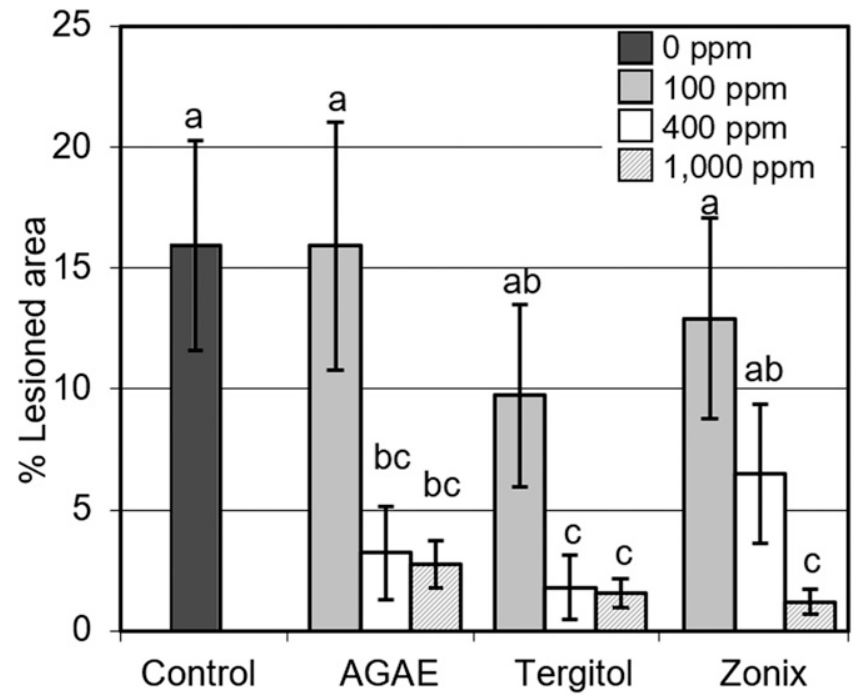

Fig. 2. Assay of all surfactant treatments to select compounds for further testing. Surfactants were tested at 100,400 , or 1,000 ppm active ingredient when mixed with deionized (DI) water and compared with a DI water control $(n=20)$. Percent lesioned area was measured 10 days after application of Phytophthora ramorum zoospores to nonwounded, treated rhododendron leaves. Data for two trials are combined. Bars represent standard error. Lowercase letters indicate significant differences between means as detected with a Fischer's least significant difference test $(P<0.05)$. 
Zonix, however, demonstrated the best efficacy over time and protection against zoospore dips, and prevented sporulation. This suggests that latex-based FFPs such as Anti-Stress may be effective at blocking the formation of sporangia, whereas terpene-based FFPs such as $\mathrm{Nu}$-Film are not. Alternatively, Nu-Film might not sufficiently spread across the surface of the leaf as to prevent sporulation in the absence of additional surfactant. This latter explanation seems unlikely given Nu-Film's efficacy at preventing infection by zoospores, its marketing as a sticker-spreader, and its low-molecular weight. Rather, the addition of Zonix may have provided some activity otherwise lacking in Nu-Film. Some cyclic lipopeptides, a class of compounds including rhamnolipids, have been shown to deform conidia (D'aes et al. 2010); therefore, it is possible Zonix might affect sporangia development. Different surfactant-FFP combinations could be equally effective as the Nu-Film-Zonix combination we tested. Of particular interest would be an Anti-Stress and Zonix combination.

Adjuvant products such as Nu-Film may increase the chance or intensity of phytotoxicity when applied with chemical additives, although they are unlikely to cause direct damage. Despite physiological changes associated with a reduction in transpiration (for example, changes in temperature regulation) (Gale and Hagan 1966), FFPs have not been shown to have any significant negative effects on overall plant health and, in some cases, treatment has resulted in higher yields and larger plants (Elad et al. 1990; Haggag 2002; Percival et al. 2006; Percival and Boyle 2009; Sutherland and Walters 2002). The effects of surfactants have been mixed, with some reports of decreases in plant mass with some application methods (Nielsen et al. 2006). Although no phytotoxic effects were observed at the tested concentrations, surfactants have been shown to be phytotoxic in cases where they change the cell membrane structure of plant tissues (D'aes et al. 2010; Vatsa et al. 2010).

The factors more likely to affect usage, however, will be reduced efficacy when plants are subjected to rain events, the dependence upon complete coverage, and the need for repeated application accounting for plant growth. Although efficacy did not decline for some treatments in the first container yard durability trial with overhead irrigation, efficacy declined for most treatments with the onset of autumn rains in the second trial, becoming no more protective than controls between 3 and 4 weeks postapplication. The second trial was applied during a dry period, meeting the minimum label recommendation dry interval. However, it is possible that the combination of higher humidity and more frequent rain events was sufficient to require a more frequent application. This time interval is on par with conventional fungicides for which foliar reapplication intervals of 30 days are common and within label parameters. Our application methods in later trials did not target the undersides of leaves.
However, because plants were sprayed individually, a greater coverage was most likely obtained than what occurs during some standard nursery operations. Further experience will be needed to determine which application protocols will be most practical and will best meet grower objectives.

The reduction in sporulation by Anti-Stress, Zonix, and the $\mathrm{Nu}-$ Film-Zonix mixture (but, interestingly, not Nu-Film alone) without the reduction in symptom development is particularly important. Contact fungicides have not been shown to consistently reduce mycelial growth and zoospore germination rates in vitro, or lesion size and infection frequency of rhododendron by $P$. ramorum (Chastagner et al. 2008; Elliott et al. 2015; Garbelotto et al. 2009; Linderman and Davis 2008; Tjosvold et al. 2008). Still, the utility of contact fungicides has not yet been fully evaluated for control of ramorum leaf blight, largely due to their poor performance relative to systemic fungicides (Elliott et al. 2015). Best evidence has been demonstrated for copper fungicides, which have been shown to prevent infection of California bay laurel and true fir by $P$. ramorum (Chastagner et al. 2008; Garbelotto et al. 2009). Reports of copper efficacy have been mixed when applied to rhododendron. Copper hydroxide prevented the spread of $P$. ramorum between rhododendron plants in one trial, reduced lesion development in another trial, and reduced lesion size in detached-leaf assays (Nechwatal et al. 2010); however, other reports found little or no effect of copper on lesion size or the number of infection sites (Chastagner et al. 2008; Tjosvold et al. 2008). Although copper may provide benefits similar to those of the proposed FFPsurfactant treatments, phytotoxicity, accumulation in soil, and the effects on nontarget organisms also need to be considered.

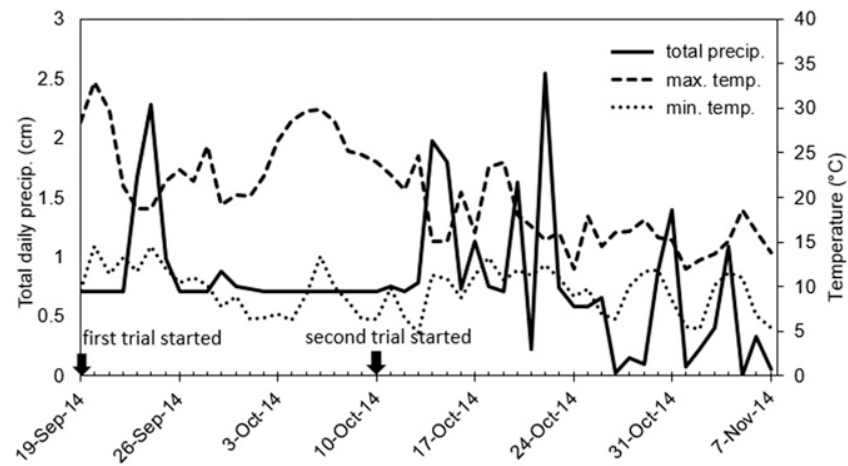

Fig. 3. Total daily precipitation (precip. = rain plus supplemental irrigation, when applicable) and daily maximum and minimum temperatures (temp.) in the container yard during the durability trial, which was performed twice in autumn 2014. Leaves were sampled weekly for 4 weeks postapplication in each trial.

Table 2. Average percent lesioned area for all film-forming polymer and surfactant treatments in the container yard trials testing foliar treatment durability over time $^{\mathrm{z}}$

\begin{tabular}{|c|c|c|c|c|c|}
\hline Treatment & Time 0 & Week 1 & Week 2 & Week 3 & Week 4 \\
\hline \multicolumn{6}{|l|}{ Trial 1} \\
\hline Control & $92.0 \mathrm{a}$ & $78.9 \mathrm{a}$ & $77.1 \mathrm{a}$ & $75.9 \mathrm{a}$ & $61.6 \mathrm{a}$ \\
\hline 500 ppm Zonix & $59.4 \mathrm{~b}$ & $68.8 \mathrm{ab}$ & $68.8 \mathrm{ab}$ & $66.8 \mathrm{ab}$ & $43.7 \mathrm{ab}$ \\
\hline 1,000 ppm Zonix & $41.2 \mathrm{~b}$ & $65.5 \mathrm{ab}$ & $55.8 \mathrm{bc}$ & $53.7 \mathrm{bc}$ & $41.8 \mathrm{~b}$ \\
\hline 5\% Anti-Stress & $47.1 \mathrm{~b}$ & $56.5 \mathrm{~b}$ & $58.7 \mathrm{bc}$ & $60.3 \mathrm{abc}$ & $37.9 \mathrm{~b}$ \\
\hline $5 \%$ Nu-Film & $48.3 \mathrm{~b}$ & $38.6 \mathrm{c}$ & $51.5 \mathrm{c}$ & $49.2 \mathrm{c}$ & $34.5 \mathrm{~b}$ \\
\hline \multicolumn{6}{|l|}{ Trial 2} \\
\hline Control & $68.4 \mathrm{a}$ & $70.0 \mathrm{a}$ & $48.5 \mathrm{ab}$ & $70.1 \mathrm{a}$ & $33.0 \mathrm{ab}$ \\
\hline 500 ppm Zonix & $31.6 \mathrm{bc}$ & $53.7 \mathrm{ab}$ & $52.3 \mathrm{a}$ & $56.4 \mathrm{ab}$ & $41.1 \mathrm{a}$ \\
\hline 1,000 ppm Zonix & $44.4 \mathrm{~b}$ & $68.1 \mathrm{a}$ & $51.1 \mathrm{a}$ & $47.6 \mathrm{abc}$ & $23.8 \mathrm{ab}$ \\
\hline $5 \%$ Anti-Stress & $16.8 \mathrm{c}$ & $33.6 \mathrm{c}$ & $19.9 \mathrm{c}$ & $43.6 \mathrm{bc}$ & $27.7 \mathrm{ab}$ \\
\hline $5 \%$ Nu-Film & $4.8 \mathrm{~d}$ & $30.0 \mathrm{c}$ & $27.8 \mathrm{bc}$ & $27.8 \mathrm{c}$ & $18.3 \mathrm{~b}$ \\
\hline 500 ppm Zonix $+2.5 \%$ Nu-Film & $4.9 \mathrm{~d}$ & $37.2 \mathrm{bc}$ & $35.4 \mathrm{ab}$ & $32.6 \mathrm{c}$ & $19.4 \mathrm{~b}$ \\
\hline
\end{tabular}

${ }^{\mathrm{z}}$ Leaves sprayed with various treatments were challenged with Phytophthora ramorum zoospores the day of application (time 0 ) and weekly for 4 weeks in a detached-leaf assay $(n=24$ per treatment on each assessment date). Letters indicate differences between treatments within a single time period as detected with a Fischer's least significant difference test $(P<0.05)$. 
Systemic chemical fungicides fosetyl-Al (Aliette) and mefenoxam (Subdue MAXX) are the compounds most commonly applied in North American nurseries to control $P$. ramorum. Although these can slow epidemic development, they have two large drawbacks: the development of tolerance and fungistatic impacts on lesion development. Mefenoxam-resistant and -tolerant isolates have been

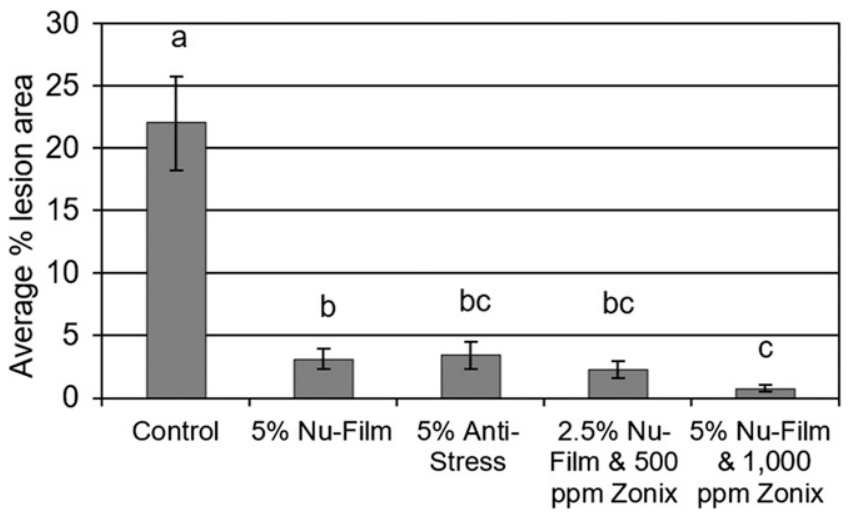

Fig. 4. Branch dip in infested surface water. Branches were clipped from treated rhododendron plants, then dipped in a zoospore suspension to simulate exposure to infested puddle water and incubated for 7 days before measuring percent lesioned area of the leaves. Control branches were clipped from rhododendrons sprayed with deionized water. Data are presented as average percent lesioned area per branch $(n=28)$ and combined for two trials. Bars represent standard error. Lowercase letters indicate significant differences between means as detected with a Fischer's least significant difference test $(P<0.05)$.
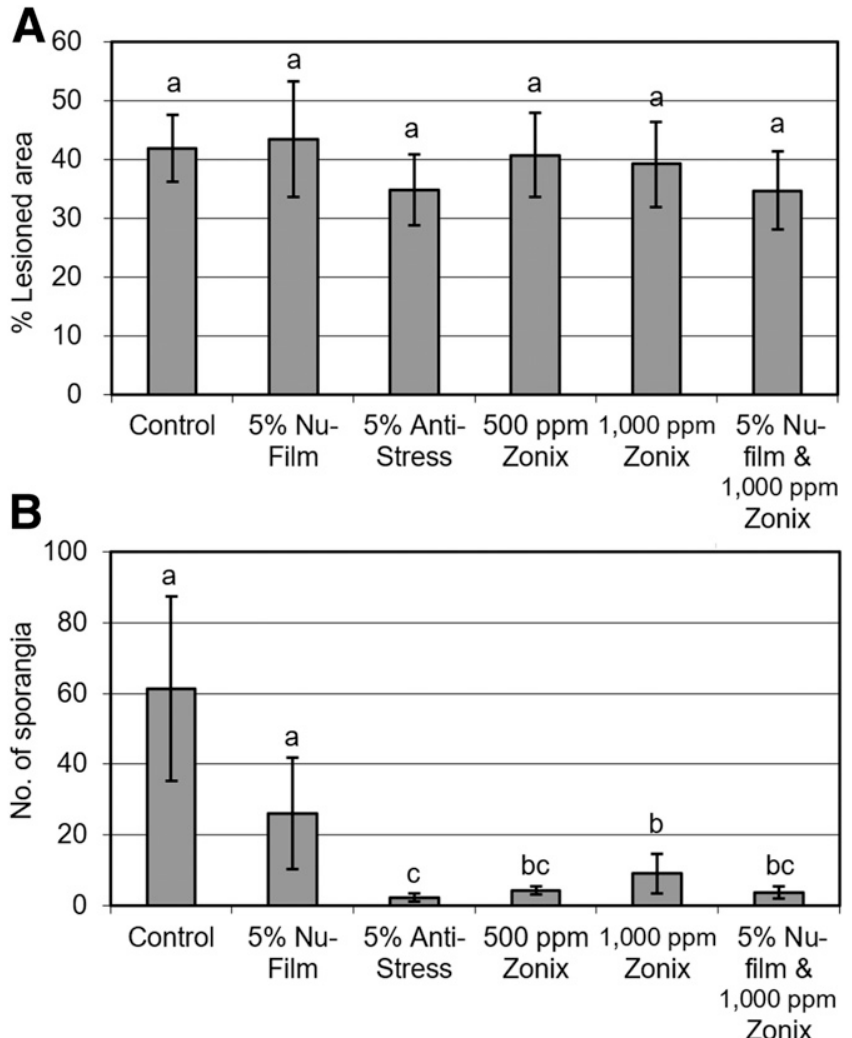

Fig. 5. Effect of foliar treatments upon A, lesion development and B, sporulation when applied 4 days after inoculation with Phytophthora ramorum zoospores. Leaves $(n=$ 20) were incubated four more days before filtering and counting of sporangia within two random transects at $\times 100$, and measuring lesion area. Control leaves were sprayed in deionized water. Data for two trials are combined. Bars represent standard error. Lowercase letters indicate significant differences between means as detected with a Fischer's least significant difference test $(P<0.05)$. detected in European $P$. ramorum populations (Pérez-Sierra et al. 2011; Vercauteren et al. 2010). Importantly, other studies have shown that, when applied postinfection, both mefenoxam and fosetyl-Al are fungistatic rather than fungicidal, only reducing the development of lesions so long as treatments are applied (Chastagner et al. 2010; Linderman and Davis 2008; Silva et al. 2016; Tjosvold et al. 2008). Given that inspections for P. ramorum are typically based on visual identification of symptoms, lesion-reducing compounds simultaneously reduce the chances of detection.

In contrast, FFPs and FFP-surfactant mixtures have the double benefit of reducing infection and sporulation while also allowing for infested plants to be detected. This could be of use to nurseries accepting new plants or propagation stock, particularly those identified as potentially infested with $P$. ramorum via trace forward tracking, or to heritage gardens hoping to slow epidemic development while delineating the extent of infection on their grounds. Although costly in comparison with conventional fungicides, a surfactant-FFP treatment would be a viable option under such circumstances as quarantine periods or when fungicides are not allowed. As a protectant with multiple modes of action, the risk of resistance development is also greatly reduced in comparison with fungicides with a single mode of action (Brent and Hollomon 2007). These treatments will additionally likely work against other foliar Phytophthora spp., as well as on other hosts to P. ramorum.

Phytophthora spp. are prevalent within horticulture nursery stock, which has been repeatedly implicated as responsible for moving invasive species into wildlands (Bienapfl and Balci 2014; Jung et al. 2016, 2018; Parke et al. 2014; Schwingle et al. 2007; Yakabe et al. 2009). FFPs and surfactants offer additional solutions for Phytophthora management as a component of an integrated pest management program. Of the compounds and combinations tested, Anti-Stress was the best stand-alone product, although the greatest protection against epidemic development was achieved with a Nu-Film + Zonix combination. Both treatments were effective in preventing infection by Phytophthora zoospores and the production of sporangia when applied postinfection. The greatest benefits might be realized during quarantine periods because, unlike fosetyl-Al and mefenoxam, these topical treatments allow for disease detection while also reducing the risk of further establishment of $P$. ramorum on site. This evidence suggests that these treatments may be applicable in bolstering the efficacy of prevailing quarantine practices, aiding in the reduction of Phytophthora spp. spread by nurseries.

\section{Literature Cited}

Bienapfl, J. C., and Balci, Y. 2014. Movement of Phytophthora spp. in Maryland's nursery trade. Plant Dis. 98:134-144.

Brasier, C., Kirk, S., and Rose, J. 2004. Sudden oak death (Phytophthora ramorum) discovered on trees in Europe. Mycol. Res. 108:1108-1110.

Brasier, C., and Webber, J. 2010. Sudden larch death. Nature 466:824-825.

Brent, K. J., and Hollomon, D. W. 2007. Fungicide Resistance in Crop Pathogens: How Can it be Managed? 2nd, revised ed. FRAC Monogr. 1. Fungicide Resistance Action Committee, Brussels, Belgium.

Cave, G. L., Randall-Schadel, B., and Redlin, S. C. 2008. Risk analysis for Phytophthora ramorum Werres, de Cock \& Man in't Veld, causal agent of sudden oak death, ramorum leaf blight, and ramorum dieback. USDAAPHIS-PPQ. https://www.aphis.usda.gov/aphis/ourfocus/planthealth/plantpest-and-disease-programs/pests-and-diseases/phytophthora-ramorum/ct phytophthora_ramorum_sudden_oak_death

Chastagner, G. A., Coats, K., and Elliott, M. 2013. An overview of Phytophthora ramorum in Washington State. Pages 14-15 in: Proc. Sudden Oak Death Fifth Sci. Symp. S. J. Frankel, J. T. Kliejunas, K. M. Palmieri, and J. M. Alexander, tech. coords. Gen. Tech. Rep. PSW-GTR-243. U.S. Department of Agriculture, Forest Service, Pacific Southwest Research Station, Albany, CA, U.S.A.

Chastagner, G. A., DeBauw, A., and Riley, K. 2008. Effectiveness of fungicides in protecting conifers and rhododendrons from Phytophthora ramorum. Pages 325-333 in: Proc. Sudden Oak Death Third Sci. Symp. S. J. Frankel, J. T. Kliejunas, and K. M. Palmieri, tech. coords. Gen. Tech. Rep. PSW-GTR214. U.S. Department of Agriculture, Forest Service, Pacific Southwest Research Station, Albany, CA, U.S.A.

Chastagner, G. A., DeBauw, A., and Riley, K. 2010. Effect of fungicides on the isolation of Phytophthora ramorum from symptomatic and asymptomatic rhododendron leaf tissue. Pages 302-304 in: Proc. Sudden Oak Death Fourth Sci. Symp. S. J. Frankel, J. T. Kliejunas, and K. M. Palmieri, eds. Gen. Tech. Rep. PSW-GTR-229. U.S. Department of Agriculture, Forest Service, Pacific Southwest Research Station, Albany, CA, U.S.A. 
COMTF. 2016. USA Phytophthora ramorum nursery chronology. California Oak Mortality Task Force (COMTF). http://www.suddenoakdeath.org/wp-content/ uploads/2016/05/Nursery_Chronology_5.10.16.pdf

D'aes, J., De Maeyer, K., Pauwelyn, E., and Höfte, M. 2010. Biosurfactants in plant-Pseudomonas interactions and their importance to biocontrol. Environ. Microbiol. Rep. 2:359-372.

Davidson, J. M., Wickland, A. C., Patterson, H. A., Falk, K. R., and Rizzo, D. M. 2005. Transmission of Phytophthora ramorum in mixed-evergreen forest in California. Phytopathology 95:587-596.

De Jonghe, K., de Dobbelaere, I., Sarrazyn, R., and Höfte, M. 2005. Control of brown roto rot caused by Phytophthora cryptogea in the hydroponic forcing of witloof chicory (Cichorium intybus var. foliosum) by means of a nonionic surfactant. Crop Prot. 24:771-778.

de Souza, J. T., de Boer, M., de Waard, P., van Beek, T. A., and Raaijmakers, J. M. 2003. Biochemical, genetic, and zoosporicidal properties of cyclic lipopeptide surfactants produced by Pseudomonas fluorescens. Appl. Environ. Microbiol. 69:7161-7172.

Elad, Y., Ayish, N., Ziv, O., and Katan, J. 1990. Control of grey mould (Botrytis cinerea) with film-forming polymers. Plant Pathol. 39:249-254.

Elliott, M., Shamoun, S. F., and Sumampong, G. 2015. Effects of systemic and contact fungicides on life stages and symptom expression of Phytophthora ramorum in vitro and in planta. Crop Prot. 67:136-144.

Ellison, A. M., Bank, M. S., Clinon, B. D., Colburn, E. A., Elliot, K., Ford, C. R., Foster, D. R., Kloeppel, B. D., Knoepp, J. D., Lovett, G. M., Mohan, J., Orwig, D. A., Rodenhouse, N. L., Sobczak, W. V., Sinson, K. A., Stone, J. K., Swan, C. M., Thompson, J., Von Holle, B., and Webster, J. R. 2005. Loss of foundation species: Consequences for the structure and dynamics of forested ecosystems. Front. Ecol. Environ. 3:479-486.

Eyre, C. A., Kozanitas, M., and Garbelotto, M. 2013. Population dynamics of aerial and terrestrial populations of Phytophthora ramorum in a California forest under different climatic conditions. Phytopathology 103: 1141-1152.

Gale, J., and Hagan, R. M. 1966. Plant antitranspirants. Annu. Rev. Plant Physiol. 17:269-282.

Garbelotto, M., Harnik, T. Y., and Schmidt, D. J. 2009. Efficacy of phosphonic acid, metalaxyl-M and copper hydroxide against Phytophthora ramorum in vitro and in planta. Plant Pathol. 58:111-119.

Goss, E. M., Larsen, M., Chastagner, G. A., Ginvens, D. R., and Grünwald, N. J. 2009. Population genetic analysis infers migration pathways of Phytophthora ramorum in US nurseries. PLoS Pathol. 5:e1000583.

Grünwald, N. J., Garbelotto, M., Goss, E. M., Heungens, K., and Prospero, S. 2012. Emergence of the sudden oak death pathogen Phytophthora ramorum. Trends Microbiol. 20:131-138.

Grünwald, N. J., Goss, E. M., and Press, C. M. 2008. Phytophthora ramorum: A pathogen with a remarkably wide host range causing sudden oak death on oaks and ramorum blight on woody ornamentals. Mol. Plant Pathol. 9:729-740.

Haggag, W. M. 2002. Application of epidermal coating antitranspirants for controlling cucumber downy mildew in greenhouse. Plant Pathol. Bull. 11: 69-78.

Haggag, W. M., and El-Khair, H. 2007. Application of some natural compounds for management of potato late and early blights. J. Food Agric. Environ. 5: 157-163.

Haun, G., and Hebbar, P. 2011. APHIS National Plant Board Phytophthora ramorum regulatory working group reports. USDA-APHIS-PPQ. https:// www.aphis.usda.gov/aphis/ourfocus/planthealth/plant-pest-and-diseaseprograms/pests-and-diseases/phytophthora-ramorum/ct_phytophthora_ ramorum_sudden_oak_death

Heungens, K., De Dobbelaere, I., Gehesquière, B., Vercauteren, A., and Maes, M. 2010. Within-field spread of Phytophthora ramorum on rhododendron in nursery settings. Pages 72-75 in: Proc. Sudden Oak Death Fourth Sci. Symp. S. J. Frankel, J. T. Kliejunas, and K. M. Palmieri, eds. Gen. Tech. Rep. PSW-GTR-229. U.S. Department of Agriculture, Forest Service, Pacific Southwest Research Station, Albany, CA, U.S.A.

Heungens, K., Gehesquière, B., Van Poucke, K., Vercauteren, A., and Maes, M. 2013. Pathways of spread of Phytophthora ramorum in a simulated nursery setting: An update. Page 53 in: Proc. Sudden Oak Death Fifth Sci. Symp. S. J. Frankel, J. T. Kliejunas, K. M. Palmieri, and J. M. Alexander, tech. coords. Gen. Tech. Rep. PSW-GTR-243. U.S. Department of Agriculture, Forest Service, Pacific Southwest Research Station, Albany, CA, U.S.A.

Hsieh, T. F., and Huang, J. W. 1999. Effect of film-forming polymers on control of lily leaf blight caused by Botrytis elliptica. Eur. J. Plant Pathol. 105:501-508.

Irish, B. M., Correll, J. C., and Morelock, T. E. 2002. The effect of synthetic surfactants on disease severity of white rust on spinach. Plant Dis. 86:791-796.

Jung, T., Orlikowski, L., Henricot, B., Abad-Campos, P., Aday, A. G., Aguin Casal, O., Bakonyi, J., Cacciola, S. O., Cech, T., Chavarriaga, D., Corcobado, T., Cravador, A., Decourcelle, T., Denton, G., Diamandis, S., Dogmus-Lehtijaervi, H. T., Franceschini, A., Ginetti, B., Green, S., Glavendekic, M., Hantula, J., Hartmann, G., Herrero, M., Ivic, D., Horta Jung, M., Lilja, A., Magnano di San Lio, G., Mansilla Vazquez, P. J., Marcais, B., Matsiakh, I., Milenkovic, I., Moricca, S., Nagy, Z. A., Nechwatal, J., Olsson, C., Oszako, T., Pane, A., Paplomatas, E. J., Pintos Varela, C., Prospero, S., Rial Martinez, C., Rigling, D., Robin, C., Rytkoenen, A., Sanchez, M. E., Sanz Ros, A. V., Scanu, B., Schlenzig, A.,
Schumacher, J., Slavov, S., Solla, A., Sousa, E., Stenlid, J., Talgo, V., Tomic, Z., Tsopelas, P., Vannini, A., Vettraino, A. M., Wenneker, M., Woodward, S., and Pérez-Sierra, A. 2016. Widespread Phytophthora infestations in European nurseries put forest, semi-natural and horticultural ecosystems at high risk of Phytophthora diseases. For. Pathol. 46:134-163.

Jung, T., Pérez-Sierra, A., Durán, A., Horta Jung, M., Balci, Y., and Scanu, B. 2018. Canker and decline diseases caused by soil- and airborne Phytophthora species in forests and woodlands. Persoonia 40:182-220.

Kamvar, Z. N., Larsen, M. M., Kanaskie, A. M., Hansen, E. M., and Grünwald N. J. 2015. Spatial and temporal analysis of populations of the sudden oak death pathogen in Oregon forests. Phytopathology 105:982-989.

Kim, B. S., Lee, J. Y., and Hwang, B. K. 2000. In vivo control and in vitro antifungal activity of rhamnolipid B, a glycolipid antibiotic, against Phytophthora capsica and Colletrotrichum orbiculare. Pest Manage. Sci. 56 1029-1035

Linderman, R. G., and Davis, E. A. 2008. Evaluation of chemical agents for the control of Phytophthora ramorum and other species of Phytophthora on nursery crops. Plant Health Prog. 9

Manter, D. K., Kolodny, E. H., Hansen, E. M., and Parke, J. L. 2010. Virulence, sporulation, and elicitin production in three clonal lineages of Phytophthora ramorum. Physiol. Mol. Plant Pathol. 74:317-322.

McPherson, B. A., Mori, S. R., Wood, D. L., Kelly, M., Storer, A. J., Svihra, P., and Standiford, R. B. 2010. Responses of oaks and tanoaks to the sudden oak death pathogen after $8 \mathrm{y}$ of monitoring in two coastal California forests. For. Ecol. Manage. 259:2248-2255.

Nechwatal, J., Haug, P., Huber, C. V., and Jung, T. 2010. Studies on the control of Phytophthora ramorum on Rhododendron for the development of management strategies in parks and gardens. Gesunde Pflanzen 62:53-62.

Nielsen, C. J., Ferrin, D. M., and Stanghellini, M. E. 2006. Efficacy of biosurfactants in the management of Phytophthora capsica on pepper in recirculating hydroponic systems. Can. J. Plant Pathol. 28:450-460.

Nielsen, T. H., Sørensen, D., Tobiasen, C., Anderson, J. B., Christophersen, C. Givskov, M., and Sørensen, J. 2002. Antibiotic and biosurfactants properties of cyclic lipopeptides produced by fluorescent Pseudomonas spp. from the sugar beet rhizosphere. Appl. Environ. Microbiol. 68:3416-3423.

Parke, J. L., Knaus, B. J., Fieland, V. J., Lewis, C., and Grünwald, N. J. 2014. Phytophthora community structure analyses in Oregon nurseries inform systems approaches to disease management. Phytopathology 104:1052-1062.

Percival, G. C., and Boyle, S. 2009. Evaluation of film forming polymers to control apple scab (Venturia inequalis (Cooke) G. Wint.) under laboratory and field conditions. Crop Prot. 28:30-35

Percival, G. C., Keary, I. P., and Marshall, K. 2006. The use of film-forming polymers to control Guignardia leaf block and powdery mildew on Aesculus hippocastanum L. and Quercus robur L. Aboricult. Urban For. 32:100-107.

Pérez-Sierra, A., Álvarez, L. A., Vercauteren, A., Heugens, K., and Abad-Campos, P. 2011. Genetic diversity, sensitivity to phenylamide fungicides and aggressiveness of Phytophthora ramorum on Camellia, Rhododendron and Viburnum plants in Spain. Plant Pathol. 60:1069-1076.

Perneel, M., D'hondt, L., De Maeyer, K., Adiobo, A., Rabaey, K., and Höfte, M 2008. Phenazines and biosurfactants interact in the biological control of soilborne diseases caused by Pythium spp. Environ. Microbiol. 10:778-788.

R Core Team. 2015. R: A Language and Environment for Statistical Computing. R Foundation for Statistical Computing, Vienna, Austria. http://www.R-project. org/

Rizzo, D. M., Garbelotto, M., Davidson, J. M., Slaughter, G. W., and Koike, S. T. 2002. Phytophthora ramorum as the cause of extensive mortality of Quercus spp. and Lithocarpus densiflorus in California. Plant Dis. 86:205-214

Ron, E. Z., and Rosenberg, E. 2001. Natural roles of biosurfactants. Environ. Microbiol. 3:229-236.

Schwingle, B. W., Smith, J. A., and Blanchette, R. A. 2007. Phytophthora species associated with diseased woody ornamentals in Minnesota nurseries. Plant Dis. 91:97-102.

Silva, P. V., Vélez, M. L., Hernández Otano, D., Nuñez, C., and Greslebin, A. G. 2016. Action of fosetyl-al and metalaxyl against Phytophthora austrocedri. For. Pathol. 46:54-66

Stanghellini, M. E., Kim, D. H., Rasmussen, S. L., and Rorabaugh, P. A. 1996a. Control of root rot of peppers caused by Phytophthora capsici with a nonionic surfactant. Plant Dis. 80:1113-1116.

Stanghellini, M. E., and Miller, R. M. 1997. Biosurfactants: Their identity and potential efficacy in the biological control of zoosporic plant pathogens. Plant Dis. 81:4-12.

Stanghellini, M. E., Rasmussen, S. L., Kim, D. H., and Rorabaugh, P. A. 1996b. Efficacy of nonionic surfactants in the control of zoospore spread of Pythium aphanidermatum in a recirculating hydroponic system. Plant Dis. 80:422-428.

Stanghellini, M. E., and Tomlinson, J. A. 1987. Inhibitory and lytic effects of a non-ionic surfactant on various asexual stages in the life cycle of Pythium and Phytophthora species. Phytopathology 77:112-114.

Sutherland, F., and Walters, D. R. 2002. Effect of film-forming polymers on infection of barley with the powdery mildew fungus, Blumeria graminis $\mathrm{f}$ sp. hordei. Eur. J. Plant. Pathol. 108:385-389.

Tjosvold, S. A., Buermeyer, K. R., Blomquist, C., and Frankel, S. 2005. Nursery guide for diseases caused by Phytophthora ramorum on ornamentals: Diagnosis 
and management. University of California Division of Agriculture and Natural Resources Publication 8156. https://anrcatalog.ucanr.edu/pdf/8156.pdf

Tjosvold, S. A., Koike, S. T., and Chambers, D. L. 2008. Evaluation of fungicides for the control of Phytophthora ramorum infecting Rhododendron, Camellia, Pieris, and Viburnum. Plant Health Prog. 9.

Tubajika, K. M., Bulluck, R., Shiel, P. J., Scott, S. E., and Sawyer, A. J. 2006. The occurrence of Phytophthora ramorum in nursery stock in California, Oregon, and Washington states. Plant Health Prog. 7.

USDA-APHIS. 2011. APHIS-National Plant Board Phytophthora ramorum regulatory working group reports. G. Haun and P. Hebbar, co-chairs United States Department of Agriculture-Animal and Plant Health Inspection Service (USDA-APHIS). https://www.aphis.usda.gov/plant_health/plant_pest_ info/pram/downloads/pdf_files/NPB-RWGR.pdf

USDA-APHIS. 2013. List of regulated hosts and plants proven or associated with Phytophthora ramorum. United States Department of Agriculture-Animal and Plant Health Inspection Service (USDA-APHIS) https://www.aphis.usda.gov/ aphis/ourfocus/planthealth/plant-pest-and-disease-programs/pests-anddiseases/phytophthora-ramorum/ct_phytophthora_ramorum_sudden_oak_ death

Varnier, A.-L., Sanchez, L., Vatsa, P., Boudescocque, L., Garcia-Brugger, A., Rabenoelina, F., Sorokin, A., Renault, J.-H., Kauffmann, S., Pugin, A., Clement, C., Baillieul, F., and Dorey, S. 2009. Bacterial rhamnolipids are novel MAMPs conferring resistance to Botrytis cinerea in grapevine. Plant Cell Environ. 32:178-193.
Vatsa, P., Sanchez, L., Clement, C., Baillieul, F., and Dorey, S. 2010. Rhamnolipid biosurfactants as new players in animal and plant defense against microbes. Int. J. Mol. Sci. 11:5095-5108.

Vercauteren, A., De Dobbelare, I., Grünwald, N. J., Bonants, P., van Bockstaele, E., Maes, M., and Heungens, K. 2010. Clonal expansion of the Belgian Phytophthora ramorum populations based on new microsatellite markers. Mol. Ecol. 19:92-107.

Walters, D. R. 1992. The effects of three film-forming polymers, with and without a polyamine biosynthesis inhibitor, on powdery mildew infection of barley seedlings. Ann. Appl. Biol. 120:41-46.

Walters, D. R. 2006. Disguising the leaf surface: The use of leaf coating for plant disease control. Eur. J. Plant Pathol. 114:255-260.

Werres, S., Marwitz, R., Man in’t Veld, W. A., de Cock, W. A. M., Bonants, P. J. M., de Weerdt, M., Themann, K., Ilieva, E., and Baayen, R. P. 2001. Phytophthora ramorum sp. nov., a new pathogen on Rhododendron and Viburnum. Mycol. Res. 105:1155-1165.

Yakabe, L. E., Blomquist, C. L., Thomas, S. L., and MacDonald, J. D. 2009. Identification and frequency of Phytophthora species associated with foliar diseases in California ornamental nurseries. Plant Dis. 93:883-890.

Zekaria-Oren, J., Eyal, Z., and Ziv, O. 1991. Effect of film-forming compounds on the development of leaf rust on wheat seedlings. Plant Dis. 75:231-234

Ziv, O., and Frederiksen, R. A. 1987. The effect of film-forming antitranspirants on leaf rust and powdery mildew incidence on wheat. Plant Pathol. 36:242-245. 